\title{
THE WILLINGNESS OF MOTIVATIONS TO FUND THE VISUAL GAME PROJECT: A CASE STUDY IN CROWDFUNDING FROM VISUAL NOVEL GAME - XAGIA WARS
}

\author{
Atik Aprianingsih"), Teresia Debby ${ }^{* *}$, Iqro Setiawan Jati*), Ira Fachira*) \\ ${ }^{*}$ School of Business and Management, Institut Teknologi Bandung \\ Jl. Ganesha No.10, Bandung 40132, Indonesia \\ ${ }^{* *}$ Universitas Katolik Parahyangan \\ J1. Ciumbuleuit No.94, Cidadap, Bandung, 40141, Indonesia
}

\begin{abstract}
Nowadays, crowdfunding is an alternative way to find funds to develop a product or service. It is no exception for game creators who want to get funds to develop the games they will create. This study is unique and was made based on a case study of Xagia Wars, a visual game created by a game creator in Jakarta called Vifth Floor. This study analyzes the motivations to increase a funder's willingness to fund a visual game project. This study used observation and netnography to get data and regression analysis to measure the motivation to fund the visual game project. The results showed that the factors that influence the funders' willingness to fund are the level of innovation of the project, reward, involvement, and support for the project. Several things need to be considered for project creators to increase the rate of successful crowdfunding. Such as the value of the reward, whether it makes people interested, a visual game must-have innovation, and invite the funders to participate in the game creation process so that funders can provide support for what is needed is not only in the form of funds.
\end{abstract}

Keywords: crowd-funding, funding, game, visual novel game

Abstrak: Saat ini crowdfunding menjadi salah satu alternatif untuk mencari dana dalam mengembangkan suatu produk atau jasa tidak terkecuali bagi para kreator game yang ingin mendapatkan dana untuk mengembangkan game yang akan mereka buat. Studi ini unik dan dibuat berdasarkan studi kasus Xagia Wars, sebuah visual game yang dibuat oleh kreator game di Jakarta bernama Vifth Floor. Tujuan dari penelitian ini untuk mengetahui motivasi untuk meningkatkan kesediaan pemberi dana untuk mendanai proyek game visual. Penelitian ini menggunakan observasi, netnografi, dan analisis kuantitatif untuk mengukur motivasi kesediaan mendanai proyek game visual. Hasil penelitian menunjukkan bahwa faktor-faktor yang mempengaruhi kesediaan pemberi dana untuk mendanai adalah tingkat inovasi proyek, penghargaan, keterlibatan, dan dukungan terhadap proyek. Beberapa hal perlu diperhatikan bagi pembuat proyek untuk meningkatkan tingkat keberhasilan crowdfunding. Seperti nilai dari hadiah yang diberikan apakah membuat orang tertarik, inovasi game visual yang harus dimiliki, dan mengajak pemberi dana untuk berpartisipasi dalam proses pembuatan game agar pemberi dana bisa memberikan dukungan yang tidak hanya berupa dana saja.

Kata kunci: crowdfunding, pendanaan, game, game visual novel

\footnotetext{
${ }^{1}$ Corresponding author:

Email: teresia_debby@unpar.ac.id
} 


\section{INTRODUCTION}

Funding is an essential process in every business. Without it, no business can get started. There are many ways to get the needed funding, like borrowing money from financial institutions, using savings, or crowdfunding. Crowdfunding is a new way to gather the funds needed for specific products or projects initiated by a particular company or individual to the general public (Zheng et al. 2014). Understanding the intricate crowdfunding process is necessary since the crowdfunding process involves many human interactions and behaviors. There are many variables involved like innovation, decision making, goal setting, but the essential variable for any successful crowdfunding will be a complete trust between the funders and the company as marketing researchers and psychologists concluded (Jenkins (2009) also Iyengar and Lepper (2000)). In every crowdfunding, there are three stages: preparing the material for the campaign, introducing the product to the public, and finally following through to the project goal (Hui et al. 2013, April).

Many researchers like Bradford (2012), Collins and Pierrakis (2012), and Song et al. (2015, April) have categorized crowdfunding based on the received rewards by the funders. There are four categories, donation crowdfunding, reward crowdfunding, lending crowdfunding, and equity crowdfunding. As the name suggests, donation crowdfunding is when crowdfunding is to donate something for charitable purposes. Then reward crowdfunding is crowdfunding when the funders get something in return, and lending crowdfunding is when the funders expect to get some interest from the money they lend to the company. Lastly, equity crowdfunding happens when the funders get a certain percentage of the profit based on their contribution to the crowdfunding.

The number of projects launched on Kickstarter between April $28^{\text {th }} 2009$, to April 2020 is around 482,136 projects encompassing 15 categories. Some categories dominate the number of projects, like games, music, and movies. The reason is that those categories have notorious experience of not getting enough funding from traditional means like financial institutions or venture capitals. The games category takes the most funding in Kickstarter, $\$ 1.24$ billion from $\$ 4.88$ billion. Independent game creators have de facto opened their market models to consumers by participating in crowdfunding projects, resulting in a new form of value creation (Zott and Amit, 2010; Chesbrough, 2003; Djelassi and Decoopman, 2013).

This paper used a study case taken from Xagia Wars. It is a visual novel game produced by Vifth Floor. Vifth Floor is a games developer based in Jakarta and was co-founded by a group of students from University Indonesia. They are trying to be recognized in the international market because Indonesia's number of successful game developers is meager. A visual novel game is a fictional narrative in interactive media that requires users' input to progress the story. The main difference between classic novels and visual novels is the interactivity needed from the player to progress. According to Dennis" "The role of Visual Novel as Narrative Medium," visual novel is a genre of video games that focus more on the storyline and less on the gameplay (Geest, 2015). In a visual novel, the text box around the character is a must because the games must clarify which character is talking or having a thought. The text box contains the dialogue of the characters and 'your own words' and frequently ideas. Where there are more than two characters, the displayed character changes according to who is speaking, and frequently, the text from separate characters is denoted by a distinct color.

Xagia Project will be using crowdfunding as its source of funding. This project is planned to use the funding schema used by Vifth Floor in their first successful game, Just Desserts. First, the Xagia team project will use the Prefundia to increase awareness and public interest. Then after getting enough coverage, they will release the Kickstarter page for the actual funding. The problem experienced during the last crowdfunding comes from using the pre-funding platform (Prefundia) as a campaign. During that crowdfunding process, only 46 potential funders were following the page. This situation will affect the success of crowdfunding on Kickstarter. The goal is to get $\$ 9000$ to fund the project successfully. View from the gathering the fund issue in Xagia Wars' project, this paper aims to get information about factors that influence willingness to fund a particular project. 


\section{METHODS}

This study used observation and netnography to get the data and process the data using regression analysis. The observation method gathers information about other virtual games looking for funds on Kickstarter. This observation was made within two months to successfully collect the right data about rewards. The information from observation is about the number of rewards each visual game offers, the most favorite and the least favourite rewards picked by funders in each visual game. These observation results can be used to know what kind of campaign is more effective based on the rewards offered.

The second method is netnography. Since netnography is a type of research highly involved in participation observation, data can take three forms: (a) data directly collected by the researcher; (b) data generated by capturing and recording online community events and interactions; and (c) data sketched by the researcher as field notes (Kozinets, 2010). For the analysis and interpretation: a stage where research does some classification, analysis of coding, and contextualization of communicative acts, Kozinets (2010) points out that all these steps must follow research ethics. In order to collect the data for this study, the researchers will be used to look for keywords connected to reasons for funders funding the project, and the keywords will be classified to get results. Lastly, to process data, it will be divided into two steps, descriptive and data analysis. For the data analysis, this study used regression analysis.

Crowdfunding is becoming ever more popular in the scientific community. It indicates the number of journal publications and studies related to it. This popularity has other advantages, such as the shift from qualitative case studies (Lasrado and Lugmayr, 2013; De Buysere et al. 2012; Fisk et al. 2011) to exploratory quantitative analysis (Belleflamme et al. 2013; Mollick, 2012).

Astudy led by Fisk et al. (2011) conducted a comparative study of two forms of crowdfunding, while Mollick (2012) conducted a detailed exploratory study over nearly 50.000 Kickstarter projects, including an indepth insight into the complexities of crowdfunding success and failure. Lambert and Schwienbacher (2010) conducted an insightful analysis in which they described the effects of evaluating questionnaire responses from
21 entrepreneurs. As a result, the entrepreneur's primary motive is to raise funds, although other motives include gaining recognition and receiving input from the public. Schwienbacher and Larralde (2010) conducted another report on an organization that uses crowdfunding to collect money, using interviews and questionnaires. The results show three advantages of using crowdfunding to collect money: getting the requisite capital, expanding one's network, and having a love of supporters who share the enthusiasm of creating a company.

According to numerous current publications and studies, there are (at least) two significant findings in the crowdfunding process. First, consider crowdfunding motivates people to help a specific project or product. According to Gerber et al. (2012), funders' motivation is to help businesses or people with similar values and expertise. It indicates that the funders want to enter and become a part of a group. Second, Belleflamme et al. (2014) identified three aspects of crowdfunding. A crowdfunding project or product usually aims to fill a hole in the market. As a result, the entrepreneur who produces the project or product must clarify the project or product's specifics. Two, funders will reserve the commodity until it is made available to the general public. Three, funders are active in all aspects of the crowdfunding operation, from fundraising to merchandise delivery.

Many crowdfunding platforms give project creators much flexibility regarding the quantity and kind of prizes they may provide in a project. Project creators may give financial gains to funders in exchange for a monetary commitment; such financial benefits have been regarded as drivers for financing success. According to Ryu and Kim (2016), the reward is the degree to which a funder wants to acquire something worthwhile in exchange for sponsoring. Average backers will always seek the highest benefit or return on their investment (Hockenbury and Hockenbury, 2003). According to Jian and Shin (2015), the fun aspect of crowdfunding stems from the novelty value of giving and the empowerment that funders experience while giving. Personal connection implies that the funders support a project because they have a personal relationship with the project creator. According to Fisk et al. (2011), about half of a project's target capital comprises investments from persons directly related to the initiative or the project creator's network. 
When projects raise much greater funds than planned before, these projects are occasional and provide real breakthroughs and innovations (Profatilov et al. 2015). Also, Pierrakis and Collins (2013) mentioned that becoming a part of an entrepreneurial venture or supporting an individual or business will play a significant part in many funders' investment decisions. A review of online discussions showed that some customers perceive themselves as supporters and invest in helping motives. According to Fisk et al. (2011), funders want to aid and support the project and the project creators. Also, many funders identify with the projects they choose to finance when they utilize crowdfunding to support good causes they believe in. Moreover, Fisk et al. (2011) also mentioned that funders want to be a part of the project they pick to fund and be at least somewhat responsible for the success of others. In general, funders are motivated to join in crowdfunding projects by a desire to collect rewards or financial returns, to assist those in need and to support a cause, and to create relationships and become a part of a community (Galuszka and Brzozowska, 2016; Lam and Law, 2016; Gerber and Hui, 2013).

Trusting the project creators implies that funders sponsor a project because the project creator is seen as trustworthy. Trust creates favorable anticipation of the total of all acts made by funders. It will foster a positive attitude, increasing the willingness to invest in crowdfunding projects on the site (See-To and Ho, 2014). Meanwhile, to Fisk et al. (2011), a chain reaction occurs at a certain point, causing more and more funders to fund a project. It means that funders behave like investors in financial herding (Devenow and Welch, 1996); they imitate and repeat the actions of other funders because they rely on primary funders' judgments and think this to be more credible than their information (Masson et al. 2001). So, a project that has received funds from another funder is another factor that influences other funders to invest in the project because the behavior of other funders influences them. The hypotheses that can be made based on the literature review:

$\mathrm{H}_{1}$. The innovative project significantly influences the willingness to fund the visual novel game crowdfunding project.

$\mathrm{H}_{2}$. Support the project significantly influences the willingness to fund the visual novel game crowdfunding project.

$\mathrm{H}_{3}$. Good cause has a significant positive influence on the willingness to fund the visual novel game crowdfunding project.

$\mathrm{H}_{4}$. Involvement has a significant positive influence on the willingness to fund the visual novel game crowdfunding project.

$\mathrm{H}_{5}$. Trust to project creator has a significant positive influence on the willingness to fund the visual novel game crowdfunding project.

$\mathrm{H}_{6}$. A project that received an initial fund significantly influences the willingness to fund the visual novel game crowdfunding project.

$\mathrm{H}_{7}$. The reward has a significant positive influence on the willingness to fund the visual novel game crowdfunding project.

$\mathrm{H}_{8}$. The fun project significantly influences the willingness to fund the visual novel game crowdfunding project.

$\mathrm{H}_{9}$. Fun in crowdfunding significantly influences the willingness to fund the visual novel game crowdfunding project.

$\mathrm{H}_{10}$. The personal connection significantly influences the willingness to fund the visual novel game crowdfunding project.

\section{RESULTS}

Based on the observation done in Kickstart in two months, six other visual novel game titles are competing for funding, such as A More Beautiful World, The Masquerade Killer, Episicava, Revival of Queen Leyak, One Last Crane, and Our Feelings. This observation focused on the number of rewards offered, the amount of rewards value, and the number of pledgers to make a visual game come true. Below are two tables that will explain further the reward aspect of the crowdfunding process. Table 1 will explain the number of rewards offered in each project, and Table 2 will explain the most preferred reward for each project.

Table 1. The comparison of reward options from observation

\begin{tabular}{lc}
\hline Kickstarter Project Title & Reward Options \\
\hline A More Beautiful World & 12 \\
The Masquerade Killer & 12 \\
Episicava & 10 \\
Revival of Queen Leyak & 8 \\
One Last Crane & 14 \\
Our Feeling & 10 \\
Xagia Wars & 16 \\
\hline
\end{tabular}


Table 2. The most and the least preferred reward from 6 visual novel games based on observation

\begin{tabular}{|c|c|c|c|c|c|c|c|c|c|}
\hline \multirow{2}{*}{$\begin{array}{l}\text { Kickstarter } \\
\text { Project Title }\end{array}$} & \multicolumn{4}{|c|}{ Rewards } & \multirow{2}{*}{$\begin{array}{c}\text { Total } \\
\text { Pledgers }\end{array}$} & \multicolumn{4}{|c|}{ Rewards } \\
\hline & $\begin{array}{c}\text { Most Preferred } \\
\text { Reward }\end{array}$ & Price & $\begin{array}{l}\text { Price } \\
(\$)\end{array}$ & $\begin{array}{l}\text { Number of } \\
\text { Pledgers }\end{array}$ & & $\begin{array}{c}\text { Least Preferred } \\
\text { Reward }\end{array}$ & Price & $\begin{array}{l}\text { Price } \\
(\$)\end{array}$ & $\begin{array}{l}\text { Number of } \\
\text { Pledgers }\end{array}$ \\
\hline $\begin{array}{l}\text { A More } \\
\text { Beautiful } \\
\text { World }\end{array}$ & Digital game & $\$ 15$ & $\$ 15$ & 107 & 204 & $\begin{array}{l}\text { Physical copy of } \\
\text { the game + OST + } \\
\text { Gimmick Reward } \\
\text { (In game map print) } \\
+ \text { Coloured sketch } \\
+ \text { Minor Character } \\
\text { Draw Request }\end{array}$ & $\$ 300$ & $\$ 300$ & 1 \\
\hline $\begin{array}{l}\text { The Mas- } \\
\text { querade } \\
\text { Killer }\end{array}$ & $\begin{array}{l}\text { Digital game + } \\
\text { Wallpaper }\end{array}$ & S\$17 & $\$ 13$ & 122 & 243 & Wallpaper x4 & $\mathrm{S} \$ 7$ & $\$ 5$ & 1 \\
\hline Episicava & $\begin{array}{l}\text { Digital game + } \\
\text { Wallpaper }\end{array}$ & $\$ 10$ & $\$ 10$ & 120 & 285 & Wallpaper & $\$ 5$ & $\$ 5$ & 0 \\
\hline $\begin{array}{l}\text { Revival } \\
\text { of Queen } \\
\text { Leyak }\end{array}$ & $\begin{array}{l}\text { Digital game + } \\
\text { Wallpaper }\end{array}$ & $\$ 10$ & $\$ 10$ & 157 & 265 & Wallpaper pack & $\$ 5$ & $\$ 5$ & 1 \\
\hline $\begin{array}{l}\text { One Last } \\
\text { Crane }\end{array}$ & $\begin{array}{l}\text { Digital game + } \\
\text { Wallpaper + Digital } \\
\text { OST + Digital Art- } \\
\text { book + Gimmick } \\
\text { (Love Letter) }\end{array}$ & $¥ 1,728$ & $\$ 15$ & 89 (limited) & 256 & $\begin{array}{l}\text { Digital Game + Wall- } \\
\text { paper + Digital Love } \\
\text { Letter + Digital OST } \\
\text { + Digital Artbook + } \\
\text { End Credit + Digital } \\
\text { Light Novel + Digi- } \\
\text { tal Manga + Early } \\
\text { Access + Personal } \\
\text { Sketch + Story Scene } \\
\text { Request + In game } \\
\text { Character Design } 3 \\
\text { (Heroine best friend) }\end{array}$ & $¥ 8100$ & $\$ 750$ & 1 \\
\hline \multirow[t]{2}{*}{ Our Feeling } & $\begin{array}{l}\text { Digital game + } \\
\text { Wallpaper }\end{array}$ & $\$ 10$ & $\$ 10$ & 142 & 301 & $\begin{array}{l}\text { Digital Game + } \\
\text { Physical Game + } \\
\text { Wallpaper + Acces- } \\
\text { sory (Pin) + Artbook } \\
+ \text { Body Pillow }+ \\
\text { Accessory ( } 5 \text { couple } \\
\text { keychain) + In game } \\
\text { Maid Design }\end{array}$ & $\$ 750$ & $\$ 750$ & 0 \\
\hline & & Average & $\$ 12$ & 123 & 259 & & Average & $\$ 303$ & 1 \\
\hline
\end{tabular}

As shown in Table 1, Xagia Wars has the highest rewards option compared to other projects; this is a disadvantage rather than an advantage. With too many options to choose from, the funders will get paralyzed. This phenomenon is explained very clearly from the book called 'The Paradox of Choice' by Barry Schwartz. Then in Table 2, it can be seen that the most preferred reward from 6 projects is around $\$ 10$ to $\$ 15$, which has an average of $\$ 12.5$. Additionally, the least preferred reward from 6 projects is around $\$ 303$. It can be assumed that the most preferred is closely related to the price. The lower the price of the reward, the more funders will participate.

Then after doing observation on Kickstarter, the research will continue with netnography. Netnography is the method of conducting research based on the words used by the users in a specific website to have a general idea of what is going on. The participation of the users heavily influences netnography. The data can be taken using three forms: researchers collect the data directly, the data can be gathered through capture and record of online community events and interactions, and data can be taken from field notes (Kozinets, 2010).

The netnography research undertaken here examines funders' motivations and preferences for visual novel crowdfunding projects, as well as their features. It also researches reward preferences. However, this study is limited to visual novel game projects, particularly fantasy ones, utilizing Kickstarter and the Lemmasoft forum as stepping stones and awareness campaigns. Ten visual novel projects are utilized to dig up the keywords, six of which are already funded via Kickstarter, and four of which are aspiring Kickstarter projects from the Lemmasoft forums. The result of netnography can be 
seen in Table 3. The netnography findings from many forum threads on related games will be discussed in detail below.

\section{Masquerade Killer}

The Masquerade Killers' compiled keywords are as follows: interesting story (7), great visual (4), great soundtrack (2), previously made a game (2), has demo (3), scheduled update (1), and finally, interesting character (1).

\section{Episicava}

The following keywords were compiled for the Episicava project: interesting story (3), has demo (2), reward-related talk (2), great visual (1), great soundtrack (1), and interesting character (1).

\section{A More Beautiful World}

The combined keywords for the A More Beautiful World project are as follows: reward-related (16), has demo (3), great soundtrack (2), and great visual (1).

\section{Revival of Queen Leyak}

The Revival of Queen Leyak project's keywords are as follows: reward-related (16), interesting character (5), great visuals (2), interesting story (1), and got steam release (1).

\section{Last Crane}

The Last Crane project's keywords are as follows: reward-related (3), interesting story (1), and has demo (1).

\section{Our Feeling}

The following keywords were compiled for the Our Feeling project: genre-related (3), reward-related (3), great visual (2), and finally, interesting story (2).

\section{Lisistrata}

The following keywords were generated for the Lisistrata project: great visual (4), interesting story (1), have easter eggs (1), and finally, interesting character (1).

\section{Reimi no Gakuen}

The combined keywords for the Reimi no Gakuen project are as follows: interesting story (4), great visuals (2), and great soundtrack (2).

\section{As we know it}

The gathered keywords for the As We Know It project are as follows: great visual (5), interesting story (4), and have branching story (1).

\section{Nusantara Bermuda}

The following keywords were generated for the Nusantara Bermuda project: previously made a game (13), interesting characters (8), great visuals (7), has demo (6), interesting story (5), and scheduled update (5).

Data on the regression analysis is from 181 respondents spread in Indonesia, the United States of America, Australia, Canada, the United Kingdom, Singapore, and other countries. The questionnaire on this study is distributed on online platforms that have active member groups discuss the visual game, such as Facebook group, online forum, and Line group, Discord, direct message to funders on a crowdfunding platform specializing in games or visual novels project in 2 months. The demographic is split into several categories; gender, age, and location. The result of demographic statistics can be seen in Table 4 .

Table 3. Keywords from netnography results

\begin{tabular}{lc}
\hline Implications & Total \\
\hline Reward Related & 40 \\
Interesting Story & 28 \\
Great Visual & 28 \\
Interesting character & 16 \\
Made game before & 15 \\
Has Demo & 15 \\
Scheduled updates & 6 \\
Great Soundtrack & 7 \\
Genre Related & 3 \\
Have Easter Eggs & 1 \\
Have branchings & 1 \\
Got steam release & 1 \\
\hline
\end{tabular}


On a scale of one to seven, most of the average lies on 4 to 6 , which indicates that some points need improvement, while others have already achieved a great score (Table 5). With this indicator, the highest average was achieved "I decided to become a funder because I want to support the project" (6.08). While "I decided to become a funder because the project has already received substantial funding," was achieved the lowest average (3.92).

From the test result (Table 6), it can be concluded that the $\mathrm{F}$ value that comes up is 3.173 with a significance of 0.001 . The significance is below 0.05 , so we can infer that the motivations affect the willingness to fund the project. The following result that will be looked at is the T-test. The variables that will be looked into are the reward, fun (project), fun (crowdfunding), supporting reason, good cause, innovative, involvement, received funding, trustworthy creator, and finally, personal connection with the project creator.

Based on the results (Table 7), not all dependent variables are significant at the $10 \%$ level (m_fun_project, n_fun_ crowdfunding, $m$ _good_cause, $m$ _trusted). The results show that a willingness to fund is not influenced by fun (project), fun (crowdfunding), good cause, and trusty creator. However, other motivations such as reward, supporting reason, innovative, want to be part of the process positively affect willingness to fund. Meanwhile, connection with creator and significantly receiving funds have a negatively significant effect on willingness to fund. Below are the results of this study:

$\mathrm{H}_{1}$. The innovative project significantly influences the willingness to fund the visual novel game crowdfunding project. (supported)

$\mathrm{H}_{2}$. Support the project significantly influences the willingness to fund the visual novel game crowdfunding project. (supported)

$\mathrm{H}_{3}$. Good cause has a significant positive influence on the willingness to fund the visual novel game crowdfunding project. (rejected)

$\mathrm{H}_{4}$. Involvement has a significant positive influence on the willingness to fund the visual novel game crowdfunding project. (supported)

$\mathrm{H}_{5}$. Trust to project creator has a significant positive influence on the willingness to fund the visual novel game crowdfunding project. (rejected)

$\mathrm{H}_{6}$. A project that received an initial fund significantly influences the willingness to fund the visual novel game crowdfunding project. (rejected)

$\mathrm{H}_{7}$. The reward has a significant positive influence on the willingness to fund the visual novel game crowdfunding project. (supported)

$\mathrm{H}_{8}$. The fun project significantly influences the willingness to fund the visual novel game crowdfunding project. (rejected)

$\mathrm{H}_{9}$. Fun in crowdfunding significantly influences the willingness to fund the visual novel game crowdfunding project. (rejected)

$\mathrm{H}_{10}$. The personal connection significantly influences the willingness to fund the visual novel game crowdfunding project. (rejected)

Table 4. Demographic statistics of respondents

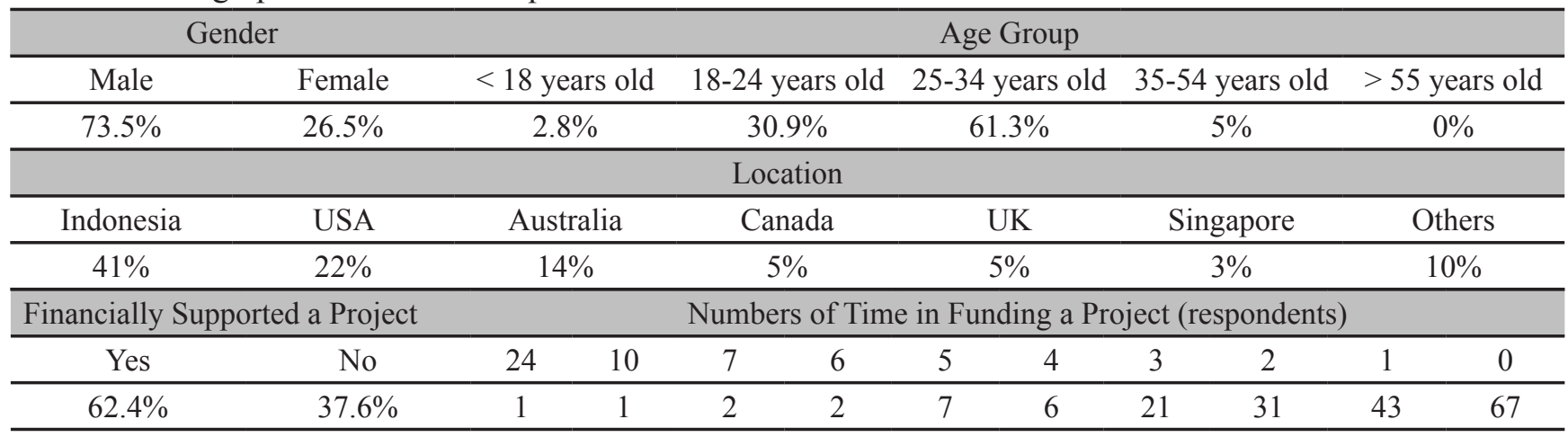


Table 5. Mean score for funders' motivations

\section{Indicators}

(I decided to become a funder because ...)

Mean Score

I receive appealing rewards.

5.8805

the project is fun.

5.5912

being involved in crowdfunding is fun.

4.2704

I want to support the project.

6.2390

the project contributed to a good cause.

4.7170

the project is innovative.

4.6478

I am able to be involved in the development process.

4.3648

the project has already received a substantial amount of funding.

3.9308

the project founders seem trustworthy.

5.5472

I had a connection to the creator (friend/family).

4.1132

Table 6. F Test Results

\begin{tabular}{lllllll}
\hline ANOVA $^{\mathbf{a}}$ & & & & & \\
\hline \multicolumn{1}{l}{ Model } & Sum of Squares & df & Mean Square & F & Sig. \\
\hline 1 & Regression & 52714.918 & 10 & 5271.492 & 3.173 & $.001 \mathrm{~b}$ \\
& Residual & 245853.519 & 148 & 1661.172 & & \\
\multicolumn{1}{l}{ Total } & 298568.437 & 158 & & & \\
\hline
\end{tabular}

${ }^{a}$ Dependent variable: willingness

b Predictors: (Constant), $\mathrm{m} \_$connection, $m \_$trusted, $\mathrm{m}$ _good_cause, $\mathrm{m}$ _fun_crowdfunding, $\mathrm{m}$ _support, $\mathrm{m}$ _fun_ project, $\mathrm{m}$-involvement, $\bar{m} \_$receivefund, $\bar{m} \_$reward, $\bar{m} \_$innovative

Table 7. T-Test for regression results

\begin{tabular}{|c|c|c|c|c|c|c|c|c|}
\hline \multicolumn{9}{|c|}{ Coefficients $^{\mathrm{a}}$} \\
\hline \multirow{2}{*}{\multicolumn{2}{|c|}{ Model }} & \multicolumn{2}{|c|}{ Unstandardized Coefficients } & \multirow{2}{*}{$\begin{array}{l}\text { Standardized } \\
\text { Coefficients Beta }\end{array}$} & \multirow[t]{2}{*}{$\mathrm{t}$} & \multirow[t]{2}{*}{ Sig. } & \multicolumn{2}{|c|}{ Collinearity Statistics } \\
\hline & & $\mathrm{B}$ & Std. Error & & & & Tolerance & VIF \\
\hline \multirow[t]{11}{*}{1} & (Constant) & -42.145 & 37.703 & & -1.118 & 0.265 & & \\
\hline & m_reward & 6.179 & 3.483 & 0.148 & 1.774 & 0.078 & 0.802 & 1.247 \\
\hline & $\mathrm{m} \_$fun_project & 0.293 & 3.160 & 0.008 & 0.093 & 0.926 & 0.830 & 1.205 \\
\hline & $\begin{array}{l}m_{-} \text {fun_crowdfund- } \\
\text { ing }\end{array}$ & 1.492 & 2.684 & 0.046 & 0.556 & 0.579 & 0.797 & 1.255 \\
\hline & m_support & 7.291 & 3.774 & 0.153 & 1.932 & 0.055 & 0.891 & 1.123 \\
\hline & m_good_cause & -5.253 & 3.304 & -0.160 & -1.590 & 0.114 & 0.547 & 1.828 \\
\hline & m_innovative & 5.140 & 2.879 & 0.172 & 1.785 & 0.076 & 0.600 & 1.668 \\
\hline & m_involvement & 4.866 & 2.364 & 0.173 & 2.059 & 0.041 & 0.789 & 1.267 \\
\hline & $\mathrm{m} \_$receivedfund & -4.611 & 2.372 & -0.161 & -1.944 & 0.054 & 0.815 & 1.227 \\
\hline & m_trust & -0.227 & 3.216 & -0.006 & -0.071 & 0.944 & 0.895 & 1.117 \\
\hline & m_connection & -5.206 & 2.257 & -0.191 & -2.306 & 0.022 & 0.811 & 1.233 \\
\hline
\end{tabular}

${ }^{\mathrm{a}}$ Dependent Variable: willingness

Based on the results, the motivation contributing significantly to the willingness to fund is innovativeness, which aligns with Fisk et al. (2011). Fisk et al. (2011) also suggest that funders who participate in crowdfunding activities like the engagement level in innovative behavior and are curious about this new investment alternative are especially true for funders looking for a new way to use the funders Internet. Another motivation that contributes significantly to the willingness to fund is to support the project. This result is in line with Gerber et al. (2012, February), which said that funders are driven by a desire to support the founder and their cause and engage with the project community. However, in this study, doing good does not significantly affect the willingness to fund. This result does not replicate the results from Henderson and Malani (2009), which said that doing good is one factor that motivates funders to participate. 
The other finding has become part of the process/ involvement, which is in line with the results from the study done by Bhattacharya et al. (1995). They stated that involvement would significantly influence the willingness to fund because involvement in a project positively affects the intention to invest in a crowdfunding project. Trust to the project creator is not proven to affect the willingness to fund significantly. This result does not imitate the result from See-To and Ho (2014). See-To and Ho (2014) mentioned that the project creator must develop the trust to create a positive expectation of the sum of all actions taken by funders. It will form a positive attitude which will improve the willingness to invest in crowdfunding projects in the platform.

Projects which receive initial funding from the other funders negatively affect willingness to fund. This result is not in line with Agrawal et al. (2015) and Fisk et al. (2011). From the result, the support of early funders will show a negative impact on the willingness to fund. At the beginning of each project, there is a certain level of uncertainty. This level of uncertainty is there because the potential funders are unsure about the ability and the project creators' intentions. The potential funders need to know for sure that the creators can be trusted and credible. Mollick (2014) stated that most Kickstarter projects would send the rewards with considerable delay. However, the rest will not deliver the rewards at all. That is one of many sources of insecurities feared by potential funders. The other source of insecurity comes from the quality of the reward. Potential funders need to know whether the project creator can transform the rewards from the idea in the early stage to the actual outcome (product) that the funders can trust. Thus, the potential funders will look for confirmation by the number of funders that have backed the projects. The number of existing funders is directly proportional to the level of trust and certainty.

In this study, the reward has a significant positive effect on willingness to fund. This result is in line with Fisk et al. (2011), Gerber and Hui (2013), and Hockenbury and Hockenbury (2003), the reward is a motivation needed by the funders, so they are willing to fund the project. The rewards can be in the form of money, products, or even email appreciation. Fun projects and fun in crowdfunding were not significantly affecting the willingness to fund. This result does not match the studies by Fisk et al. (2011), Gerber and
Hui (2013), Hockenbury and Hockenbury (2003), Bretschneider et al. (2014) and Agrawal et al. (2011). Based on Bretschneider et al. (2014), fun projects and fun in crowdfunding can be used to satisfy curiosity and become the motivations to affect willingness to fund. Meanwhile, personal connections to the project creator have a significant adverse effect on willingness to fund. This result is not in line with the result from Agrawal et al. (2011). Based on Agrawal et al. (2011), personal connection is found to be an essential group for funding reward-based crowdfunding projects. Funders tend to support projects with emotional connection and familiar identification with the creator of the projects.

\section{Managerial Implications}

This study provides important managerial implications for helping visual game creators maximize their fundraising through crowdfunding. The results of this study show that project creators must have innovative game visual ideas (e.g., new storylines and never before existed in other game visuals). The more innovative the idea, the more interesting the funders will be to provide funds to the project and vice versa. If the visual idea of the game is the same or similar to other game visuals that have existed, then funders are not interested in providing funds. In addition, other than an innovative game visual game idea, it is good for the project creator to invite funders to create the game visuals most simply, giving news about the development of visual creation the game. So that the funders will feel they are appreciated and like involved even indirectly way.

Another motivation that can spur funders in providing funds rewards. Providing several reward options by the funding provided will motivate funders in willingness to fund. It is good that the options given are not too many because it will only confuse funders with the many options for reward. In addition, it is good that the options provided include rewards with funding amounts starting from $\$ 1$ so that even funders who only give $\$ 1$ feel appreciated. In addition to rewards, deflating this project support sentence for only $\$ 1$ has another impact: funders can feel that with only $\$ 1$, they have provided support for the project. Examples of prizes that can be given for prizes worth $\$ 1$ can be in the form of a thank you note or a postcard with the theme of the game's visuals. 
The project creator should be able to include a short video about their visual game in the campaign. Also, provide a clear timeline in the process of fundraising up to the visuals of the game. In addition, selecting the right crowdfunding platform will be beneficial in achieving maximum results towards the funding of the project. It is recommended that project creators analyze the platform in advance and how many games are campaigning in the same genre as the games created by the project creator. If only a few games are the same as our game genre, our chances of getting funding will be greater than many games with the same genre.

\section{CONCLUSIONS AND RECOMMENDATIONS}

\section{Conclusions}

Crowdfunding is a new, novel, and innovative way to let anyone become funders of some projects over the Internet.Additionally, crowdfunding allows anyone who is looking to fund to help their projects. The long-term impacts of crowdfunding are still a mystery. However, one crowdfunding type (reward crowdfunding) looks like an up-and-coming method to gather funds without any help from the traditional financial institution. Some types of projects are more suitable using this method compared to others like game projects. Based on the results, the factors that influence the funders' willingness to fund are the project's level of innovation, reward, support the project, and becoming part of the project. Meanwhile, other factors such as project received initial fund, good cause, trust the project creator, fun in both crowdfunding and project, personal connections do not affect willingness to fund in visual game project crowdfunding.

\section{Recommendations}

The limitation of this study was the number of samples, which are 181 respondents. This study also used singleitem measures, where much disagreement about singleitem measures. However, Grapentine (2001) also Sarstedt and Wilczynski (2009) argue that single-item measures are appropriate for simple constructs. In the future, it is expected to use a multi-item measure so that the validity and reliability of the results can be more accurate.

In future studies, it is recommended to research other types of projects like film, technology, design, etc. The information may be used to look for some connection between the types of projects to the willingness to fund. Also, the number of samples must be increased to be more stable and representative of the population. In addition, it can be a consideration to include other variables that affect willingness to fund, such as enjoyment, recognition, and platform.

\section{REFERENCES}

Agrawal A, Catalin C, Goldfarb A. 2011. Offline relationships, distance, and the Internet: the geography of crowdfunding. https://pdfs. semanticscholar.org/8db1/93dcc337a8cc2d5759 5e3b422bdc0c0dfbe4.pdf

AgrawalA,CataliniC, GoldfarbA.2015.Crowdfunding: Geography, social networks, and the timing of investment decisions. Journal of Economics \& Management Strategy 24(2):253-274. https:// doi.org/10.1111/jems.12093

Belleflamme P, Lambert T, Schwienbacher A. 2013. Individual crowdfunding practices. Venture Capital 15(4):313-333. https://doi.org/10.1080/ 13691066.2013.785151

Belleflamme P, Lambert T, Schwienbacher A. 2014. Crowdfunding: Tapping the right crowd. Journal of Business Venturing 29(5):585-609. https:// doi.org/10.1016/j.jbusvent.2013.07.003

Bhattacharya CB, Rao H, Glynn MA. 1995. Understanding the bond of identification: An investigation of its correlates among art museum members. Journal of Marketing 59(4):46-57. https://doi.org/10.1177/002224299505900404

Bradford CS. 2012. Crowdfunding and the federal securities laws. Colum. Bus. L. Rev.1.

Bretschneider U, Knaub K, Wieck E. 2014. Motivations for crowdfunding: what drives the crowd to invest in start-ups?. http://pubs.wi-kassel.de/wpcontent/uploads/2015/04/JML_5321.pdf

Chesbrough HW. 2003. Open innovation: The new imperative for creating and profiting from technology. Massachusets: Harvard Business Press.

Collins L, Pierrakis Y. 2012. The venture crowd: Crowdfunding equity investments into business. https://eprints.kingston.ac.uk/id/eprint/29089/1/ the_venture_crowd.pdf

De Buysere K, Gajda O, Kleverlaan R, Marom D, Klaes M. 2012. A framework for European crowdfunding. https://www.fundraisingschool. 
it/wp-content/uploads/2013/02/EuropeanCrowdfunding-Framework-Oct-2012.pdf

Devenow A, Welch I. 1996. Rational herding in financial economics. European economic review 40(3-5):603-615. https://doi.org/10.1016/00142921(95)00073-9

Djelassi S, Decoopman I. 2013. Customers' participation in product development through crowdsourcing: Issues and implications. Industrial Marketing Management 42(5):683-692. https://doi. org/10.1016/j.indmarman.2013.05.006

Fisk RP, Patrício L, Ordanini A, Miceli L, Pizzetti M, Parasuraman A. 2011. Crowdfunding: Transforming customers into investors through innovative service platforms. Journal of Service Management.

Galuszka P, Brzozowska B. 2016. Early career artists and the exchange of gifts on a crowdfunding platform. Continuum 30(6):744-753. https://doi. org/10.1080/10304312.2016.1231790

Geest DVD. 2015. The role of Visual Novels as a Narrative Medium (Master's thesis).

GerberEM,HuiJ.2013. Crowdfunding:Motivations and deterrents for participation. ACM Transactions on Computer-Human Interaction (TOCHI) 20(6):1-32. https://doi.org/10.1145/2530540

Gerber EM, Hui JS, Kuo PY. 2012, February. Crowdfunding: Why people are motivated to post and fund projects on crowdfunding platforms. In Proceedings of the international workshop on design, influence, and social technologies: Techniques, impacts and ethics 2(11):10. Northwestern University Evanston, IL.

Grapentine TH. 2001. A practitioner's comment on Aimee L. Drolet and Donald G. Morrison's "Do we really need multiple-item measures in service research?".JournalofServiceResearch4(2):155158. https://doi.org/10.1177/109467050142007

Henderson MT, Malani A. 2009. Corporate philanthropy and the market for altruism. Columbia Law Review 109:571. https://doi.org/10.2139/ ssrn. 1116797

Hockenbury DH, Hockenbury SE. 2003. Psychology. Ed. ke-3. New York: Worth.

Hui J, GreenbergM,GerberE.2013,April.Understanding crowdfunding work: Implications for support tools. In CHI'13 Extended Abstracts on Human Factors in Computing Systems. hlm 889-894. https://doi.org/10.1145/2468356.2468515

Iyengar SS, Lepper MR. 2000. When choice is demotivating: Can one desire too much of a good thing?. Journal of personality and social psychology 79(6):995. https://doi. org/10.1037/0022-3514.79.6.995

Jenkins H. 2009. Confronting The Challenges Of Participatory Culture: Media Education For The 21st Century. Massachusets: MIT Press.

Jian L, Shin J. 2015. Motivations behind donors' contributions to crowdfunded journalism. Mass Communication and Society 18(2):165-185.

Kozinets RV. 2010. Netnography: Doing Ethnographic Research Online. London: Sage.

Lam PT, Law AO. 2016. Crowdfunding for renewable and sustainable energy projects: An exploratory case study approach. Renewable and Sustainable Energy Reviews 60:11-20. https://doi. org/10.1016/j.rser.2016.01.046

Lambert T, Schwienbacher A. 2010. An empirical analysis of crowdfunding. Social Science Research Network 1578175(1):23.

Lasrado LA, Lugmayr A. 2013, October. Crowdfunding in Finland: A new alternative disruptive funding instrument for businesses. In Proceedings of International Conference on Making Sense of Converging Media. hlm 194-201. https://doi. org/10.1145/2523429.2523490

Masson P, Gotur P, Lane T. 2001. International Economic Policy Review. Washington DC: International Monetary Fund (IMF).

Mollick E. 2012. The Dynamics of Crowdfunding: Determinants of Success and Failure. In Social Science Research Network (SSRN).

Mollick E. 2014. The dynamics of crowdfunding: An exploratory study. Journal of Business Venturing 29(1):1-16. https://doi.org/10.1016/j. jbusvent.2013.06.005

Pierrakis Y, Collins L. 2013. Crowdfunding: A new innovative model of providing funding to projects and businesses. Available at SSRN 2395226. https://doi.org/10.2139/ssrn.2395226

Profatilov DA, Bykova ON, Olkhovskaya MO. 2015. Crowdfunding: Online charity or a modern tool for innovative projects implementation?. Asian Social Science 11(3):146. https://doi. org/10.5539/ass.v11n3p146

Ryu S, Kim YG. 2016. A typology of crowdfunding sponsors: Birds of a feather flock together? Electronic Commerce Research and Applications 16:43-54. https://doi.org/10.1016/j. elerap.2016.01.006

Sarstedt M, Wilczynski P. 2009. More for less? A comparison of single-item and multi-item 
measures. Die Betriebswirtschaft 69(2):211.

Schwienbacher A, Larralde B. 2010. Crowdfunding of Small Entrepreneurial Ventures: Handbook of Entrepreneurial Finance. UK: Oxford University Press, Forthcoming.

See-To EW, Ho KK. 2014. Value co-creation and purchase intention in social network sites: The role of electronic Word-of-Mouth and trust-A theoretical analysis. Computers in Human Behavior 31:182-189.

Song A, Lee HI, Ko M, Lee U. 2015, April. Every little helps: Understanding donor behavior in a crowdfunding platform for non-profits. In Proceedings of the 33rdAnnual ACM Conference Extended Abstracts on Human Factors in Computing Systems. hlm 1103-1108.

Zheng H, Li D, Wu J, Xu Y. 2014. The role of multidimensional social capital in crowdfunding: A comparative study in China and US. Information \& Management 51(4):488-496.

Zott C, Amit R. 2010. Business model design: An activity system perspective. Long range planning 43(2-3):216-226. 